\title{
Meaning of work from the perspective of hospital nurses
}

\author{
Sentido do trabalho na perspectiva dos enfermeiros do âmbito hospitalar \\ Sentido del trabajo en la perspectiva de los enfermeros del ámbito hospitalario
}

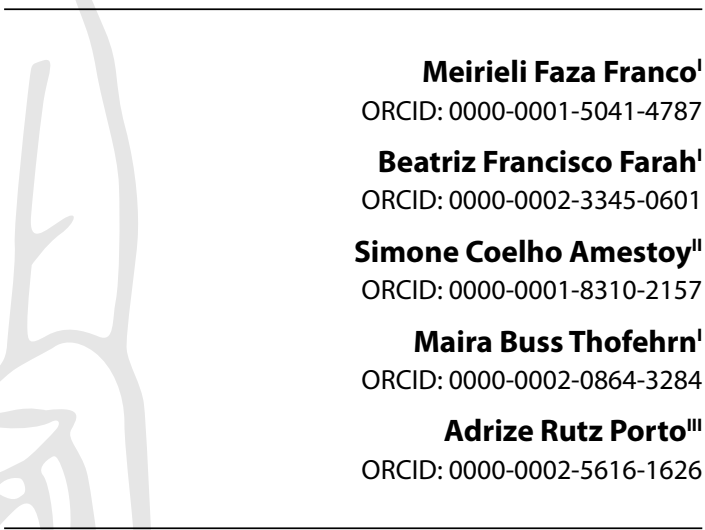

'Universidade Federal de Juiz de Fora. Juiz de Fora, Minas Gerais, Brazil.

"Universidade Federal do Vale de São Francisco. Petrolina, Pernambuco, Brazil.

I'Universidade Federal de Pelotas. Pelotas, Rio Grande do Sul, Brazil.

How to cite this article: Franco MF, Farah BF, Amestoy SC, Thofehrn MB, Porto AR. Meaning of work from the perspective of hospital nurses. Rev Bras Enferm. 2022;75(2):e20201362. https://doi.org/10.1590/0034-7167-2020-1362

\section{Corresponding author:} Meirieli Faza Franco

E-mail:meiri_faza@hotmail.com

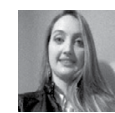

EDITOR IN CHIEF: Antonio José de Almeida Filho ASSOCIATE EDITOR: Alexandre Balsanelli

\section{ABSTRACT}

Objectives: to know the meaning of the role of nurses in the hospital environment. Methods: this is a descriptive study with a qualitative approach, whose setting was a university hospital in Minas Gerais with 50 nurses. Data were collected through interviews and analyzed according to content analysis, with the contribution of the Interface software from $R$ pour les Analyzes Multidimensionalnelles de Textes et de Questionnaires. Results: three categories emerged: "Nurses' daily work in the hospital environment"; "Work motivation as an influential factor in the meaning of work"; "The two faces of the meaning of work: pleasure and suffering". Nurses attributed a positive meaning to their work. Final Considerations: three dimensions of the meaning of work were highlighted: individual, organizational and social. These influenced the professional, social, working and individual life of nurses.

Descriptors: Nurses; Occupational Health; Job Satisfaction; Motivation; Hospitals.

\section{RESUMO}

Objetivos: conhecer o sentido do trabalho para enfermeiros do âmbito hospitalar. Métodos: estudo descritivo, de abordagem qualitativa, cujo cenário foi um hospital universitário de Minas Gerais com 50 enfermeiros. Os dados coletados por meio de entrevista e analisados conforme análise de conteúdo, com a contribuição do software Interface de R pour les Analyses Multidimensionnelles de Textes et de Questionnaires. Resultados: emergiram três categorias: "Cotidiano do trabalho dos enfermeiros no âmbito hospitalar"; "Motivação no trabalho como fator influenciador no sentido do trabalho"; "As duas faces do sentido do trabalho: prazer e sofrimento". Os enfermeiros atribuíram sentido positivo ao trabalho. Considerações Finais: evidenciaram-se três dimensões do sentido do trabalho: individual, organizacional e social. Estas influenciavam a atuação profissional, na vida social, laboral e individual do enfermeiro. Descritores: Enfermeiros; Saúde do Trabalhador; Satisfação no Emprego; Motivação; Hospitais.

\section{RESUMEN}

Objetivos: conocer el significado del trabajo del enfermero en el ámbito hospitalario. Métodos: estudio descriptivo con abordaje cualitativo, cuyo ámbito fue un hospital universitario de Minas Gerais con 50 enfermeras. Datos recogidos a través de entrevistas y analizados según análisis de contenido, con el aporte del software Interface de $R$ pour les Analyzes Multidimensionalnelles de Textes et de Questionnaires. Resultados: surgieron tres categorías: "Trabajo diario del enfermero en el ámbito hospitalario"; "La motivación en el trabajo como factor de influencia hacia el trabajo"; "Las dos caras del significado del trabajo: placer y sufrimiento". Las enfermeras atribuyeron un significado positivo al trabajo. Consideraciones Finales: se evidenciaron tres dimensiones del significado del trabajo: individual, organizacional y social. Estos influyeron en el desempeño profesional, en la vida social, laboral e individual del enfermero.

Descriptores: Enfermeros; Salud Laboral; Satisfacción en el Trabajo; Motivación; Hospitales. 


\section{INTRODUCTION}

Over the years, work has become an activity loaded with meanings in the lives of individuals, favoring social integration and personal fulfillment, as it directly influences the quality of life, thus being an activity loaded with meaning for those who work develops ${ }^{(1-2)}$.

During the development of work, feelings such as pleasure or suffering may arise due to interpersonal relationships arising from it, impacting professional performance. In nursing work, which has as its object the individual who needs specialized care, the team is constantly faced with the suffering inherent to its performance. According to a study ${ }^{(3)}$, the complexity of the tasks performed, long working hours, unhealthy environments, insufficient interpersonal relationships and the low value of professionals are factors that make nursing activities arduous.

Studies ${ }^{(2-3)}$ indicate that, regardless of these stresses, the nurses' work environment provides feelings of pleasure and satisfaction. Results from another investigation ${ }^{(4)}$ express that nurses are satisfied with performing their activities, even in the face of difficulties encountered during the work process.

Job satisfaction is understood to be a feeling defined as positive emotions or attitudes toward work, including environmental, organizational, interpersonal perspectives, and the lived experiences of workers ${ }^{(5-6)}$.

The meaning of work for this research is understood by the presence of all the dimensions involved in the development of the work according to the adopted referential $\left.\right|^{(7)}$. The individual dimension is formed by the subjectivities developed by the worker in the performance of his or her work activity, being essential the domain of specific skills, autonomy, identity, and independence. The work must be challenging and promote a permanent learning process for its accomplishment, in order to understand the individual dimension. In the social dimension, the work developed needs to be recognized and to be meaningful to the worker, to the users, and to society. Finally, in the organizational dimension, it is necessary for the worker to know the work process, the company's goals, in order to use feedback to recognize the efficiency of the work done and thus give it meaning ${ }^{(7)}$.

However, despite the existence of these broader dimensions, it is worth noting that, to develop their work, the individual needs to achieve intrinsic satisfaction. This is identified when the worker performs his or her activities, which allow the achievement of autonomy, competencies, personal motivations, expansion of knowledge and skills, thus fulfilling their internal needs, generating pleasure and consequently satisfaction in developing their work ${ }^{(8)}$.

Nurses give meaning to their work in a positive way by achieving success in the development of nursing care when, for example, a life is saved, thus becoming useful for people's well-being ${ }^{(8)}$. In this study, the aim was to understand the meaning of work for nurses, with emphasis on the subjective issues that permeated their involvement with work and that certainly influenced their attitudes and behaviors with patients and teammates.

It is noteworthy that nurses are team leaders and develop private activities that cannot be delegated to other categories, so it is necessary, in addition to technical and scientific training, professional fulfillment and job satisfaction to preserve their physical and mental health. In view of the above, the present study had as its guiding question: What is the meaning that hospital nurses give to their work?

\section{OBJECTIVES}

To know the meaning of work for nurses in the hospital environment.

\section{METHODS}

\section{Ethical aspects}

The research was approved by the Research Ethics Committee on February 28, 2018. The participating nurses who participated in the research signed the Informed Consent Form (FICF), in addition to complying with the other ethical and legal precepts.

\section{Type of study}

Descriptive research with a qualitative approach. We sought to identify the characteristics of the professionals and the phenomenon studied (the meaning of work). It is exploratory because it allows for greater familiarity with the problem, seeking to clarify it. It is understood that a qualitative approach is relevant to the study because it intends to understand and apprehend the subjective experiences of nurses regarding the phenomenon studied $^{(9)}$. The COREQ checklist was used.

\section{Methodological procedures}

Fifty nurses from the surveyed services were interconnected to participate in the investigation. Nurses who had been working for at least one year at the hospital were included. Initially, 80 nurses were selected at random, but 25 refused to participate in the research. Five nurses who were not available for time were excluded, after three approaching them at different times.

\section{Study setting and study sample}

Study carried out in a university hospital, which has two units (health care center and hospital unit) in a municipality in the state of Minas Gerais.

\section{For data collection and organization}

The interview technique was adopted, with a guiding script containing sociodemographic data to characterize the profile of nurses and questions relevant to the meaning of work, which addressed the meaning given by nurses to work; as main motivations to develop their work; factors that bring suffering and pleasure; and the meaning of being a nurse at the research institution.

Prior contact was established with the nursing coordinator for data collection at the institution. Appearance was the intent of the study; then she released a list with names of nurses, staffing sector and telephone number - through which participants were randomly recruited. The researcher contacted the professional and explained about the objectives, methodology and importance of carrying out the study. 
The interview was conducted in hospital rooms reserved to preserve the privacy of the participants, in agreement with them, and was recorded with their consent. Data collection took place between March and July 2018, and the collection was interrupted when there was an exhaustion of the reflections attending the object of study. The total recording was 10 hours and 3 minutes, with an average of 11 minutes and 40 seconds per interview. Participants assigned codes with the letter " $E$ ", which corresponds to the word "nurse", followed by the Arabic number referring to the order of the interviews.

\section{Data analysis}

For operationalize the data processing of the information, check the software Interface de R pour les Analyzes Multidimensionnelles de Textes et de Questionnaires - IRAMuTeQ, 0.7 alpha 2, licensed by GNU GPL (v2). It is a free program anchored in the R software and performs statistical processing and analysis of found texts ${ }^{(10)}$.

The textual corpus was built by the researcher to be inserted in any software containing a single text with the 50 transcribed information. The general corpus separated into 538 text segments (STs), with use of $82.71 \%$ of the words, knowing that the recommendation is a minimum retention of $75 \%{ }^{(10)}$.

After an analysis in IRAMuTeQ, Content Analysis ${ }^{(11)}$ was performed through three phases: pre-analysis; explore making material; and treatment of results (inference and interpretation).

Pre - analysis - The organization of the material was carried out, compiling the initial ideas, establishing a determined work structure, with well-defined but compliant procedures. A floating and exhaustive reading of the knowledge was carried out, seeking to know, analyze and define the main points, called "corpus". A single corpus with the 50 characteristics was created and inserted in the IRAMuTeQ software by dividing the text into units and grouping them by similarity, defining the material ${ }^{(11)}$.

Material exploration - It consisted of completing and defining the categorization of the corpus. They have been identified as registration units. The meaning unit corresponded to the content segment considered as a base unit, aiming at the categorization and frequency calculation; recognition of the corpus context units, that is, comprehension unit to encode the registration unit that represents the message segment, with a knowledge of understanding the correct meaning of the registration unit ${ }^{(11)}$.

The treatment of results (inference and interpretation) - Refers to the deepening of the analysis, establishing links with the theoretical framework on "the meaning of work", providing inferences and interpretations or unexpected discoveries ${ }^{(11)}$.

In the analysis of the textual corpus, three categories emerged, composed according to the presentation of the classes resulting from the compatibility of words: I) The daily work of nurses in the hospital environment; II) Work motivation as an influential factor in the meaning of work; III) The two faces of the meaning of work: pleasure and suffering.

\section{RESULTS}

In the Similarity Analysis (Figure 1), it was possible to observe the presentation of the words that had similarities among them and the connection between the words of the same class and among the other classes, allowing the identification of co-occurrences among the words and their result.

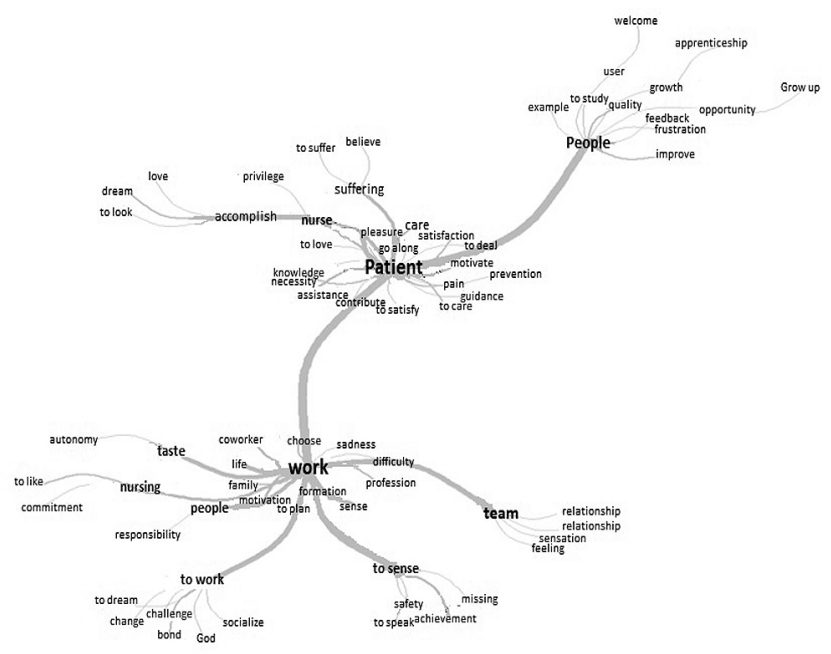

Figure 1 - Similarity analysis generated by IRAMuTeQ software (2019)

In Figure 1, it is observed that the formation of the central core structure was represented by the word "patient", and the peripheral system corresponds to the issues related to the nurse's "work" and to factors related to professional growth and development of nurses at work. In addition, the figure highlights the word "people", which is the object of the nurse's work, the human being, the patient, with his/her singularities and particularities, with whom the nurse, through an interpersonal relationship, develops care, which is the core of his/her work process.

The "work" is a peripheral branch of the tree built in Figure 1 and appears in the nurses' statements as an activity loaded with feelings, whether positive or negative, as shown in Figure 1: suffering, pleasure, satisfaction, motivation, frustration, among others.

\section{Category 1: The daily work of nurses in the hospital environment}

Despite following strict routines and protocols in their daily work, it could be noted that, when workers feel pleasure and motivation when performing their activities, they build their professional identity. This characterizes an individual dimension ${ }^{(7)}$ and contributes for them to find meaning in the work they do:

Today, thanks to God, I can say that I feel fulfilled and happy to be in my workplace, satisfied, with pleasure. (E13)

Despite all the problems related to management, which there always are, I feel very fulfilled to be a nurse, to promote the health of others. This is very rewarding. (E6)

I take great pleasure in performing my profession, in seeing the improvement of the patients' clinical picture. (E31)

The daily work performed by nurses stands out for a work that encompasses the care, management and educational dimensions:

I stayed in nursing always in the care area, the first time I was in the management area. But my work makes more sense when I'm in the direct care of my patients. (E15) 
We provide all the assistance to the patient that stays here with us: medications, baths, dressings. Ifill out the schedules. At the end of the shift, I try to do this at least once a month. I gather my staff and do a training session, for example, on the correct practice of hand hygiene. (E23)

Before I became a manager, I worked in direct patient care. I really like what I do, because I know that even if I am not present with the patient, I know that, in an indirect way, my work helps the patient's recovery. (E42)

\section{Category 2: Work motivation as an influential factor in the meaning of work of work}

The results in this category, relevant that nurses reported a motivation to perform their work at the time of providing quality care to the patient, thus linking a motivation generated in activities with the meaning given to their work.

My motivation is to be helping the patient, to be doing my best to bring comfort and well-being, both to him and his family. (E11)

I find motivation to do what I like! So I come here with pleasure, I come because I like it and I find myself extremely necessary here in the sector and in this role I work. (E6)

My biggest motivation is to always be doing what is best for the patient. (E34)

Nurses reported satisfaction and motivation to perform their work, as they were recognized by the nursing team, the multiprofessional team and especially by their work object - the patient:

It is very gratifying to see the recognition of the patient, the gratitude of the patient, of the employees. (E3)

What brings me joy is the recognition of the clientele, the family members, and the multiprofessional team. (E15)

Having the recognition of my patients and my team, seeing me as a reference, helps me to want to continue to develop my work in the best possible way. (E21)

Ifeel happy when a co-worker recognizes my effort, my care. There is nothing more pleasurable than this. (E35)

\section{Category 3: The two faces of the meaning of work: pleasure and suffering}

The nurses reported that the meaning of work was related to pleasure, thus identifying three dimensions: individual, social and organizational ${ }^{(7)}$ :

It brings a lot of satisfaction. We have a lot of annoyance, a lot of responsibility, but also a lot of satisfaction. You see people's clinical picture; and, after much effort, it gets better; this is very good, gratifying. Work complements my life; with him, I can exercise education, care. (E7)

Despite being rushed, tiring and stressful, the meaning is useful, seeing that my work brings a difference to people's lives, consequently it brings me fulfillment and a lot of pleasure. (E10)
I'm suspicious of talking because I love what I do and it brings me a sense of accomplishment and pleasure. (E40)

The suffering generated by the work can be identified by the nurses:

Suffering for me is when the patient no longer has a treatment prognosis and then palliative care is started. (E10)

What brings me suffering are everyday issues, such as the lack of material, for example, which ends up harming quality patient care. (E21)

When I am faced with a patient in the final stages of his illness [...] seeing his suffering and that of his entire family causes me an inner sorrow that I can't help but feel. (E18)

The pleasure generated by the nursing work was also identified, as shown in the following account:

For sure, what gives me the most pleasure in my work is always to do what is best for the patient [...]. (E7)

One of the things that gives me pleasure is, of course, the recognition of each patient. (E26)

To be fulfilled, doing what I like, to be able to serve the patients? this brings me great pleasure. (E38)

\section{DISCUSSION}

In this research, it was verified that the suffering reported by nurses was associated with pain and the suffering of the other, the patient, generating anguish and stress. But, at the same time, nurses find pleasure in their work, they have dreams, they enjoy what they do and the interaction with patients and the professional team. Besides, there is the possibility for the worker to expand his abilities and develop his subjectivity in the work environment. In this way, work promotes the insertion of man in society, contributing to his personal and professional growth ${ }^{(12)}$, as pointed out in this research, in the similarity tree, in the peripheral branch of the word "gente" (people) (Figure 1).

\section{Category 1: The daily work of nurses in the hospital environment}

The daily work corresponds to actions related to the work environment in a given place, with a period to happen ${ }^{(13)}$. In nursing, it is not everyday that nurses are inserted in the social environment through work, this results from their relationship with others, whether they are patients, families, professionals in the nursing team or in the interdisciplinary health team. This contributes to their learning and professional growth, as well as to the improvement of their subjectivities. These are fundamental for the formation of the professional's identity, which is built through the individuality of the being, the self, and the relationship presented between the individual and the other, between the individual and the world as a nurse and as a human being ${ }^{(13)}$.

In this study, it was verified that some nursing activities were bound to routines, since they followed norms pre-established 
by the institution. The care nurse, when taking on duty, should participate in the shift change meeting, read the occurrence book, check the emergency cart, visit the patients, and provide assistance, performing procedures that are exclusive to nurses, among other functions. The results of the present research are consistent with those of another study ${ }^{(14)}$, in which the care nurses had a work routine based on practical activities such as those cited.

The activities mentioned by nurses in managerial positions were based on administrative functions, as evidenced by the words evaluation, notification, organization, creation of protocols, request for materials, equipment, and all the management of the unit.

The nursing work process is based on the care and management spheres and is directly related to nursing practice through teaching and research. The nurse needs to present knowledge about management so that he/she can perform activities such as: administer care in all areas of service provision developed in health institutions; plan; organize; direct; require results; and, finally, evaluate the work process that involves patient care, always aiming at the quality and satisfaction of the services provided $^{(15)}$

The managerial sphere allows for the organization of the nursing work process, making it more qualified and productive. When one has a scientifically supported managerial practice, as a result, one also has professionals who are more confident in performing their activities, thus contributing positively to the final product, which is care, and to professional satisfaction ${ }^{(15)}$.

A gap was noticed between the care actions and specific content by most nurses, which is also present in most nursing services in the country ${ }^{(16)}$. Nursing care management is theoretically linked to a relationship between care and management, which are close and complement each other.

In the hospital-scenario of the study, there are positions of nurse managers and assistants, indicating the existence of a possible dichotomy between assisting and managing, due to the positions. It may be that care management is compromised, since, in order to perform it, direct care (assisting) and indirect care (which would be managing) actions must be performed in an integrated and articulated manner for a systematized and quality care to the citizens that seek nursing services ${ }^{(16)}$. Nurse manager E13 expressed the distancing of care management by nurses, when he reported missing the activities developed with the patient. However, by managing the unit through the provision of material resources, people management, and the elaboration of protocols to guide actions, it contributes to the development of quality care.

It can be identified that the dimensions of the meaning of work $^{(7)}$ existing in this category were the individual, strongly present in the daily lives of professionals, influencing the construction of professional and organizational identity of the work process, which includes actions aimed at enabling material and personnel conditions so that care can be effectively performed with quality. Thus, it was observed in the statements of the nurses participating in the study the concern with organizing and controlling the work process or managing nursing care in the hospital environment. This ratifies the nurses' organizational commitment, which is one of the variables of the organizational dimension.

\section{Category 2: Work motivation as an influential factor in the meaning of work}

Motivation is an individual feeling, which can be internal or external to the person, consciously or unconsciously. According to the human needs theory ${ }^{(17)}$, the individual's motivation is associated with the satisfaction of a high need on the scale proposed by the individual. As the needs of the lower level, which are the physiological needs, are satisfied, the individual is motivated to achieve the needs of the higher level (self-actualization). The latter can be acquired through health, comfort, well-being, professional achievement, recognition for work, progress, among other aspects ${ }^{(17)}$.

The meaning of work is intertwined with the worker's motivation, commitment, recognition and satisfaction with their work ${ }^{(18)}$. These factors were identified in the speeches of the participants, when they mentioned developing their work with satisfaction and pleasure and enjoying what they do, having a satisfactory relationship with the nursing and interdisciplinary team. In addition, they reported the opportunity to grow professionally, forming their professional identity, and to have recognition, which is a component factor of the individual dimension of the meaning of work ${ }^{(7)}$.

In the textual analysis of the IRAMuTeQ software, it was noticed that the meaning attributed to the work by the nurses brought motivation as one of the main feelings to develop meaningful work. The nurses cited the patients' recovery as a factor that motivated them to do their work, even when faced with daily situations that negatively interfered with the work process, such as lack of material or equipment needed for the treatment.

Recognition is an action that moves between suffering and pleasure in/by the work, since hospital care follows the biomedical model, which generally interferes with the user's way of recognizing and valuing the nurses' work $^{(19)}$.

The recognition and appreciation of their work are of great importance for the worker and are motivating factors, contributing to their mental health and favoring the organization of work, generating benefits for both the worker and the institution. They also contribute to the strengthening of the worker's professional and personal identity, so that he/she starts to perform the activities developed with more pleasure and satisfaction and to raise the quality of the work process ${ }^{(19)}$.

These feelings generated by work are found in the individual dimension of the meaning of work ${ }^{(7)}$, since motivation and pleasure are basic feelings to achieve job satisfaction, identity formation, and professional growth of the worker and, thus, to find the real meaning of work.

The organizational dimension of the meaning of work ${ }^{(7)}$ was identified when the participants affirmed having both recognition from their colleagues and patients and the organization of the work process, from which they feel satisfied and motivated to develop their activities.

The social dimension is also exemplified in participant E30's speech. Several nurses felt motivated when they saw that the objectives of their work were met, such as the recovery of patients for their reintegration into society.

In short, the nurse's work is recognized through the following competencies: the technical-scientific skill and ability to understand the human being as a whole; the integrity of health care; 
the ability to welcome and recognize the needs and expectations of individuals and families ${ }^{(20)}$.

Nursing is considered a social practice as it is an indispensable and relevant work for society, as its activities contribute directly to the provision of health services, through the nursing care to which it refers.

\section{Category 3: The two faces of the meaning of work: pleasure and suffering}

To be developed with meaning, work needs to be efficient and useful, to provide pleasure and autonomy, as well as satisfaction when doing it. When the worker experiences this, there is an expansion of their interprofessional interaction and also the affirmation of their personal and professional identity, thus reaching fulfillment in life and at work ${ }^{(7)}$.

If the nurse relates satisfactorily with his/her team, his/her work becomes useful, generating improvement in the quality of life of patients. By taking into account the final result of the relationship and usefulness, the worker feels inserted in society, being able to perform his activities with excellence ${ }^{(19)}$.

Nurses attributed a sense of usefulness to their work, for being able to do their best for the patient, in order to achieve the patient's well-being. For nurses to develop their work with excellence, they need to feel useful, that is, to have a return on their actions. In the case of nursing, it is the improvement in the quality of life of patients resulting from the care provided, in order to cure and rehabilitate them ${ }^{(7)}$.

The study signaled the importance of work in the worker's life. Work has become, in recent times, an activity loaded with senses and meanings, since it is through it that man builds his/her life, acquires goods, finds professional and, consequently, personal fulfillment, becoming satisfied and fulfilled in what he/she does ${ }^{(9)}$.

Another participant also related the meaning of work with having pleasure in developing his activities, being rewarding, and having the recognition of patients (individual dimension). This feeling generates in the worker a feeling of usefulness (organizational dimension), because he perceives the work process from beginning to end and recognizes that he/she is contributing with/to society (social dimension). When added together, these feelings arising from the professional's relationship with work generate professional and personal fulfillment, thus reaching the meaning of their work.

It is worth mentioning that work is a source that generates positive feelings when its purpose is understood and the human needs of the worker are met. However, during their work, nurses and their teams face difficulties in their work process, whether due to fragmentation or lack of human, financial, and material resources.

In nursing, in recent years, the rates of depression among professionals have been gradually increasing. This is due to the environments that are not favorable for the development of nursing activities, with an overload of services, lack of human and material resources, living with the pain of others and frustrations, lack of autonomy and freedom to practice the profession, interpersonal and professional conflicts, and the demands of managers. These factors maximize the risks of depression, increase the mental disorder of these professionals, and can cause suicide ${ }^{(21)}$.
It was perceived that the suffering of nurses originated from the work verified in this research was often a result of the suffering experienced by patients and family members. This research indicates that nursing participates directly in the patient's treatment process and, consequently, is often present in the process of terminality of this person ${ }^{(22)}$. Therefore, it is up to the nursing team to provide comfort, relief, and peace to these patients. As a consequence, many nurses, when dealing with the pain of others, with the fear, anguish, and revolt of patients and family members, end up manifesting the same reactions, showing that they are not prepared to deal with human frailties in relation to life and death, which generates suffering and anguish.

The work environment is a place that promotes interpersonal relationships, namely: between professionals and professionals; professionals and patient; professionals and family members ${ }^{(22)}$. When these relationships are developed in a positive, constructive, and collaborative way, we obtain group cohesion and a balance in the organizational climate, promoting pleasure and satisfaction to the professionals. On the other hand, if these relationships are performed in a disrespectful way, generating internal conflicts in the group, the worker becomes unmotivated and unsatisfied; and, consequently, a picture of suffering at work can develop ${ }^{(22)}$.

Even in the face of the sources that generate suffering, nurses find pleasure in performing their activities, associating the success achieved with patient therapy and, in turn, with the improvement of their clinical condition and recognition by these people, generating professional fulfillment and improvement in the care provided ${ }^{(23)}$.

\section{Study limitation}

This study does not seek to exhaust the discussion on the topic. Since the health area promotes social interaction through the worker's daily life, this situation consequently produces the consequences or negatives. Therefore, further studies in the research scenario are recommended, covering other professionals, in order to verify if the meaning attributed to the work by nurses in this research is present in other professionals. It is recommended that the institution promote actions that can contribute to the positive meaning of work.

\section{Contributions to Nursing, Health, or Public Policy}

The contributions for Nursing and the health area are the knowledge about the meaning of work for nurses, as well as the recognition of intervening factors that permeate the feelings and emotions experienced in the work environment. The study revealed that the work performed by nurses contributes: to the formation of their subjectivities, social inclusion, self-fulfillment, in order to achieve goals and life purposes and, thus, contributing to the formation of identity as a professional and personal; and for the improvement of the nursing service, promoting the quality of care provided.

\section{FINAL CONSIDERATIONS}

The study made it possible to understand the work of nurses in the hospital context as a social practice, historically provided, 
which develops this practice in response to the needs of the person and society. Therefore, by giving a voice to nurses who experience the daily work, it was possible to understand that they gave different meanings to work resulting from the emotions felt and factors present in the work that influenced its development. However, the most reported meaning of work is pleasure and professional satisfaction and - less present, but relevant - suffering. These feelings are important to be reflected and considered, as they interfere in the daily work, and can compromise the positive or negative way of feeling, thinking, inventing, creating and recreating your daily work.

The presence of the dimensions of the meaning of work was observed: an individual, certain factors identified for the formation of a professional identity, showing that the activities were performed with pleasure and satisfaction, allowing for personal and professional growth; the organizational, the interprofessional and interpersonal relationship emerged as an aspect that enhanced the performance of work and this as a team, with the link between the nurse-patient pointed out as a generator of pleasure and encouragement; the social dimension, in which it was seen that the professional feels useful when they identify their collaboration, through their work, for the recovery and return of the person being cared for to society. It was also found that "helping others" was perceived by professionals as an act of citizenship, demonstrating their social commitment to the right to health.

Thus, it is considered relevant that the institution's management and nursing management appropriate these results and some efforts for the development of actions that can contribute to promotional measures for a healthy work environment, making the nurses' actions a reduced action in the social, labor and individual life of these professionals, which will affect the quality of services provided at the research institution.

\section{SUPPLEMENTARY MATERIAL}

This article is the result of a master's thesis research entitled "The meaning of work for nurses in the hospital environment", related to the Graduate Program Stricto Sensu of the Faculty of Nursing at the Federal University of Juiz de Fora on June 25, 2019.

Franco MF, Farah BF, Amestoy SC, Thofehrn MB, Porto AR. Meaning of work for nurses in the hospital environment. Juiz de Fora, Minas Gerais. Dissertation [Masters in Nursing] - Faculty of Nursing, Federal University of Juiz de Fora. 2019. Access: https:// repositorio.ufjf.br/jspui/handle/ufjf/10913.

\section{REFERENCES}

1. Neves DR, Nascimento RP, Felix MS, Silva FA., Andrade ROB. Sentido e significado do trabalho: uma análise dos artigos publicados em periódicos associados à Scientific Periodicals Electronic Library. Cad EBAPE.BR. 2018;16(2):318-30. https://doi.org/10.1590/1679-395159388

2. Albornoz S. O que é trabalho. São Paulo: Brasiliense; 2017.

3. Loriol M. [The meaning of nursing work, a fragile collective construction]. Rev Infirm. 2018; 67(238):18-19. http://doi.org/10.1016/j. revinf.2017.11.022 French

4. Bonfada MS, Moura LN, Soares SGA, Pinno C, Camponogara S. Autonomia do enfermeiro no ambiente hospitalar. Enferm Bras. 2018;17(5):527-34. https://doi.org/10.33233/eb.v17i5.1503

5. Azevedo BDS, Nery AA, Cardoso J P. Estresse ocupacional e insatisfação com a qualidade de vida no trabalho da enfermagem. Texto Contexto Enferm. 2017;26(1),1-11. https://doi.org/10.1590/0104-07072017003940015

6. Choi S, Kim M. Effects of structural empowerment and professional governance on autonomy and job satisfaction of the Korean nurses. J Nurs Manag. 2019; 27(8):1664-72. http://doi.org/10.1111/jonm.12855

7. Morin EM. Os sentidos do trabalho. Rev Adm Empresas. 2007;4(3):8-19. https://doi.org/10.1590/S0034-75902001000300002

8. Gómez-Salgado J, Navarro-Abal Y, López-López MJ, Romero-Martín M, Climent-Rodríguez JA. Engagement, passion and meaning of work as modulating variables in nursing: a theoretical analysis. Int J Environ Res Public Health. 2019;16(1):108. http://doi.org/10.3390/ijerph16010108

9. Gil AC. Métodos e técnicas de pesquisa social. $6^{a}$ ed. São Paulo: Atlas, 2008.

10. Camargo BV, Justo AM. Iramuteq: um software gratuito para análise de dados textuais. Temas Psicol. 2013;21(2):513-18. https://doi. org/10.9788/TP2013.2-16

11. Bardin L. Análise de Conteúdo. São Paulo: Edições 70; 2016.

12. Landis TT, Severtsen BM, Shaw MR, Holliday CE. Professional identity and hospital-based registered nurses: a phenomenological study. Nurs Forum. 2020; 55(3):389-394. https://doi.org/10.1111/nuf.12440

13. Moreira DA, Tibães HBB, Brito MJM. Pleasure-suffering duality in stricto sensu graduate programs in nursing: between bridges and walls. Rev Bras Enferm. 2020;73(2):20180533. http://doi.org/10.1590/0034-7167-2018-0533

14. Clarke J, Baume K. Embedding spiritual care into everyday nursing practice. 2019. https://doi.org/10.7748/ns.2019.e11354

15. Treviso P, Peres SC, Silva AD. Competências do enfermeiro na gestão do cuidado. Rev Adm Saúde. 2017;17(69):59. https://doi.org/10.23973/ras.69.59

16. Lamb FA, Beck CLC, Coelho APF, Vasconcelos RO. Trabalho de enfermagem em pronto socorro pediátrico: entre o prazer e o sofrimento. Cogitare Enferm. 2019;24:e59396 https://doi.org/10.5380/ce.v24i0.59396

17. Fleming K, Mazzatta GR, Matarese K, Eberle J. Compassion fatigue and the ART model. Nursing. 2020;50(3):58-61. https://doi. org/10.1097/01.nurse.0000654168.38494.dd 
18. Backes DS. Significados da prática social do enfermeiro. Enfermagem Brasil. 2020;10(4):218-24. https://doi.org/10.33233/eb.v10i4.3866

19. Pimenta CJL, Bezerra TA, Martins KP. Pleasure and suffering among hospital nurses. Rev Bras Enferm. 2020;73(2):20180820. http://doi. org/10.1590/0034-7167-2018-0820

20. Zoboli ELCP, Schveitzer MC. Valores da enfermagem como prática social: uma metassíntese qualitativa. Rev Latino-Am Enfermagem. 2013;21(3):08 telas. https://doi.org/10.1590/S0104-11692013000300007

21. Carvalho AA. Qualidade de vida no ambiente hospitalar dos profissionais de enfermagem. Amazônia: Sci Health. 2020; 8(1):37-54. https:// doi.org/10.18606/2318-1419/amazonia.sci.health.v8n1p37-54

22. Pimentel NJS, Silva RRC, Oliveira YHA, Silva AGI. A satisfação dos trabalhadores de enfermagem como indicador de gestão. REAS. 2020;(55):e3258A. https://doi.org/10.25248/reas.e3258.2020

23. Pimenta CJL, Viana LRC, Bezerra TA, Silva CRR, Costa TF, Costa KNFM. Prazer, sofrimento e comunicação interpessoal no trabalho de enfermeiros no ambiente hospitalar. Texto Contexto Enferm. 2020;29:20190039. https://doi.org/10.1590/1980-265X-TCE-2019-0039 